infant mortality, the denominator is also increased. The effect of this is to again render even quite large percentage changes in mortality over time liable to chance variation. For example, there was an apparent decrease of $12 \cdot 1 \%$ in deaths from coronary heart disease from 1981 to 1989 for men aged 35-64 in Hull. However, the $95 \%$ confidence intervals for this change in mortality are wide $\left(-2 \cdot 7 \times 10^{+}\right.$to $1 \cdot 2 \times 10^{3}$ ) and allow the possibility either of no change or of an increase in the true mortality for men of this age. Indeed, the same uncertainty is true of the district mortality trends for all the conditions suggested in The Health of the Nation.

We suggest, therefore, that changes in death rates are a statistically inappropriate method of measuring variations over time in the health of a district population. This is a further argument for the need to develop measures of health that are not based on mortality for use at district level.

SUE IBBOTSON IAN WATT

Department of Public Health Medicine, Hull Health Authority,

Hull Health Auth
Hull HU2 8TD

1 Secretary of State for Health. The health of the nation. London: HMSO, 1991.

SIR,-Dr S Bingham, in her article on dietary aspects of a health strategy for England, recognises that health education on its own is insufficient as a policy for dietary change.' National food culture, food advertising, and nutrition labelling are appropriately highlighted as areas in need of public attention. The green paper and Dr Bingham's response to it neglect the crucial economic dimensions of personal income, food prices, and fiscal policy in agriculture.

Low income is an obstacle to healthy eating. The Department of Health's recent dietary survey shows that those in receipt of welfare benefits have comparatively low intakes of vitamins $\mathrm{C}, \mathrm{D}$, and $\mathrm{E}$ as well as calcium and magnesium. ${ }^{2}$ Foods providing dietary fibre and micronutrients, such as oranges and wholemeal bread, are expensive sources of food energy. For example, two custard cream biscuits at $3 p$ and $1 \mathrm{lb}$ of carrots at $20 \mathrm{p}$ each provides $0.42 \mathrm{MJ} .{ }^{3}$ Healthy eating is a luxury for the increasing number of those below or on the margins of poverty in Britain. In 1988, 11.8 million people, including $25 \%$ of the nation's children, were dependent on incomes of less than $50 \%$ of the average wage. ${ }^{+}$Financial hardship tends also to limit access to food. Those without a car may not be able to reach good supermarkets or to shop cheaply in bulk. ${ }^{3}$ Those without a well equipped kitchen are unable to store and prepare food in the most appropriate ways. ${ }^{3}$ There is therefore certainly a case for reviewing current levels of welfare benefit to make a healthy diet at least potentially accessible for the whole nation.

E J BRUNNER

Department of Community Medicine,

University College London,

London WC1E 6EA

1 Bingham $S$. Dietary aspects of a health strategy for England. $B M 7$ 1991;303:353-5. (10 August.)

Gregory J, Foster $\mathrm{K}$, Tyler $\mathrm{H}$, Wiseman $\mathrm{M}$. The dietary and nutritional survey of British adults. London: HMSO, 1990.

Cole-Hamilton I, Lobstein TJ. Poverty and nutrition survey. London: National Children's Homes, 1991.

4 House of Commons Social Security Committee. Low income statistics: households below average income. London: HMSO, 1991.

5 Radical Statistics Health Group. Facing the figures. London: Radical Statistics, 1987

\section{Leprosy in reaction}

SIR, - Mr A W Fowler concludes' that because the patient described by Dr A S Malin and colleagues had developed a plantar neurotrophic ulcer ${ }^{2}$ there must have been a lesion of the posterior tibial nerve. Section of the trunk of a peripheral nerve does not, however, lead to the severe trophic ulcers, mutilation, and Charcot's joints that are such a characteristic feature of leprosy. More probably this patient had developed a sensory polyneuritis with a "glove and stocking" distribútion, the features of which were described by Monrad-Krohn nearly 70 years ago $^{3}$ and confirmed by me in Nigerian patients. ${ }^{+}$This purely sensory polyneuritis can occur on its own or be associated with the more commonly described mononeuritis multiplex.

This sensory polyneuritis can be acute in onset and affect the arms and legs simultaneously, but the nerves are not necessarily tender or even enlarged and skin lesions need not be inflamed. The cardinal sign is oedema of the hands, feet, and face. ${ }^{+}$Although surgical decompression to preven protective loss of sensation would not be indicated $\mathrm{Mr}$ Fowler is right to emphasise the importance of compression, which is due not so much to enlarged nerves but to soft tissue swelling and particularly affects the median nerve at the wrist, the deep branch of the ulnar nerve, and the zygomatic and temporal branches of the facial nerve as they cross the zygomatic arch. Steroids should be given not in standardised regimens but in doses sufficient to reduce the oedema and so prevent the compression neuropathies and also to ensure the return of the sensation of pain in the hands and feet. As the syndrome is self limiting the steroids can then be tailed off.

C L CRAWFORD

Department of Anatomy

Charing Cross and Westminster Medical School,

London W6 8RF

1 Fowler AW. Leprosy in reaction. BMf 1991;303:124. (13 July.)

2 Malin AS, Waters MFR, Shehade SA, Roberts MM. Leprosy in reaction: a medical emergency. BMJ 1991;302:1324-6. (1 June.

3 Monrad-Krohn GH. The neurological aspect of leprosy. Christian Jacob Dybwad, 1923.

4 Crawford CL. Neurological lesions in leprosy. Lepr Rev 1968;39:9-13.

\section{Kala-azar in France}

SIR,-In reporting their study of kala-azar in France Dr D Jeannel and colleagues remark on the difficulty in diagnosing the disease.' They also state that "regarding the clinical signs no particular association was apparent."

While I was serving in the Indian army during the second world war the most striking feature of early kala-azar that I observed was the absence of malaise despite the patient having a high temperature. If the temperature chart showed a reading of $40^{\circ} \mathrm{C}$ and the patient was out of his bed socialising with other patients in the ward kala-aza was the most probable diagnosis. No other tropical fever has such a noticeable absence of malaise.

M D INNIS

Greensloopes Repatriation Hospital

Brisbane,
Australia

1 Jeannel D, Tuppin P, Brucker G, Danis $M$, Gentilini $M$

Imported and autochthonous kala-azar in France. $B M \mathcal{J}$ 1991;303:336-8. (10 August.)

\section{Papaveretum in women of childbearing potential}

SIR, - We, the consultant anaesthetists of West Berkshire Health Authority, are astounded by the recommendation of the Committee on Safety of Medicines that all products containing papaveretum should be contraindicated in women of childbearing potential.' This seems to have been made solely on the basis of in vitro experiments, for which no reference is given.

We believe that most anaesthetists use papaveretum as their first choice for a strong analgesic during pregnancy. This is because in the United Kingdom it is the agent of which we have the greatest experience, and there is no clinical evidence of harm to pregnancy or fetus. Unless the recommendation is withdrawn newer analgesics without this proved record of efficiency and safety may be used with consequences for the fetus yet to be discovered.

$\begin{array}{rr}\text { S ALLEN } & \text { R JAGO } \\ \text { A MARSHALL BARR } & \text { M RIMMER } \\ \text { JANE BIRD } & \text { T SMITH } \\ \text { P J BROCK } & \text { C VERGHESE } \\ \text { M C EWART } & \text { C WALDMANN } \\ \text { RACHEL HALL } & \text { E YOUNG }\end{array}$

Royal Berkshire Hospital,

Reading,

Berkshire RG1 5AN

1 Committee on Safety of Medicines. Genotoxicity of papaveretum and noscapine. Current Problems 1991 June; No 30.

SIR,-After reviewing published reports concerning the genotoxic effects of noscapine, ${ }^{12}$ the Committee on Safety of Medicines has been prompted into action. It has made several recommendations, including that papaveretum should be contraindicated in women of childbearing potential.

Papaveretum has been one of the mainstays of perioperative analgesia in the United Kingdom for the past 20 years. It consists of the hydrochlorides of opium alkaloids and contains the equivalent of anhydrous morphine $47 \cdot 5 \cdot 52 \cdot 5 \%$, anhydrous codeine $2 \cdot 5-5 \%$, noscapine $16-22 \%$, and papaverine $2 \cdot 5-7 \%$. $^{4}$ Pure noscapine hydrochloride $\left(\mathrm{C}_{22} \mathrm{H}_{23}\right.$ $\mathrm{NO}_{7}, \mathrm{HCl}, \mathrm{H}_{2} \mathrm{O}$; molecular weight $467 \cdot 9$ ) consists of colourless crystals freely soluble in water whose pharmacological actions are mainly as a centrally acting cough suppressant and smooth muscle relaxant. To review the implication of the recommendations made by the Committee on Safety of Medicines, we conducted a postal survey concerning the use of this drug.

We distributed 228 questionnaires to anaesthetists of all grades throughout the anaesthetic departments of Wessex health region. We had received 149 replies $(65 \%)$ within three weeks, when results were assessed. Only one anaesthetist was unaware of the Committee on Safety of Medicines' recommendations, and 144 had previously used papaveretum in women of childbearing potential. Two anaesthetists still pre scribed papaveretum in this group of patients despite being aware of the guidelines, but 143 anaesthetists had had to alter their practice. The guidelines have thus had widespread effect.

Of interest is the variable interpretation that the guidelines have produced. One hundred and nine anaesthetists still prescribed papaveretum to men 83 to male children, but only 34 to female children. A discrepancy thus exists concerning the prescription of papaveretum to male and female children.

The committee's guideline concerning women of childbearing potential refers to the potential of a woman to bear a child at the present time (Committee on Safety of Medicines, personal communication). The genotoxic effects of noscapine have been shown on diploid mammalian cell lines in vitro, and the rapidly dividing cells of the newly fertilised ovum are considered to be most at risk. As yet there is no work concerning genotoxicity in haploid cells, and so the interference of noscapine in gametogenesis is purely speculative. Thus the committee's recommendation does not extend to female children, although many anaesthetists have interpreted the guidelines to include this group. 